\title{
Government Information Policy and
}

\section{the Future of \\ the Depository Library Program}

\author{
Marie L. Clark
}

Author's Note: This article states the personal, professional concerns of a documents librarian who has witnessed, over the last twenty years, the decrease in freely accessible information from the U.S. government to the citizens of the government services. This decrease in information received through the Depository Library Program impacts library budgets dramatically.

Democracy - a state of society characterized by formal equality of rights and privileges; the common people of a community as distinguished from any privileged class; the common people with respect to their political power. ${ }^{I}$

The political power of a people is dependent upon the information it possesses. James Madison articulated that relationship very clearly in 1822 :

\section{A popular government, without popular information, or the means of acquiring it, is but a Prologue to a Farce or a Tragedy; or, perhaps both. Knowledge will forever govern ignorance; and a people who mean to be their own Governors must arm themselves with power which knowledge gives. ${ }^{2}$}

The federal government's Depository Library Program is the American people's "means of acquiring" information by and about their government. Evolving federal information policy suggests 1990 is the year Madison's Prologue ends anad the Farce or Tragedy begins.

Originating with legislation in $1812^{3}$ and strengthened by Congress in 1869 when the position of Superintendent of Documents was established and charged with the duty of "packing and distributing" public documents free to depository libraries and to various officials, ${ }^{4}$ the Depository Library Program has come to be accepted by many librarians and their patrons as a guarantee. However, the erosion of the Depository Library Program has been going on for over ten years. This new decade may see irrevocable changes

Marie L. Clark is Head of the Public Documents/Maps Department at Perkins Library, Duke University, Durham. that will affect the "common people" and their ability to acquire information by and about their government.

Why is this happening? Who is responsible for the present situation? The blame can be spread democratically among many groups. It can be placed on federal administrators and on Congressionally elected representatives who are responsible for formulating federal information policy. It can be placed on those in the Information Industry Association who have lobbied for the right to access and sell government information at a profit. And it can be placed on the library profession which has often failed to provide adequate access to depository collections.

In the last ten years two benchmarks in the formation of federal information policy stand out: The Paperwork Reduction Act (PRA) of 1980 (44 USC 3501 et. seq.) and the Office of Management and Budget (OMB)'s Circular A-130, issued on December 24, 1984 (50 FR 52730). The combination of the PRA's stated intent "to reduce paperwork and enhance the economy and efficiency of the government and the private sector by improving Federal information policy making," ${ }^{, 5}$ and A130 's criteria that the information to be collected by agencies have "practical utility" that could be "demonstrated" by showing that the "expected public and private benefits from government information... should exceed the public and private costs of the information" 6 has resulted in the significant erosion of public information disseminated through the Depository Library Program.

Through the PRA and Circular A-130, the Reagan administration established the principle of privatization of public information, that is, the selling of public information by the private sector. This principle was further strengthened by the recommendations of the President's Private Sector Survey on Cost Control and by passage of the Gramm-Rudman-Hollings Budget Reduction Act 
of 1985. The Information Industry Association (IIA) gained ground through these measures, the result of IIA's lobbying efforts and claims that the private sector should not be subjected to the "unfair competition" of the free distribution of government produced information through the Depository Library Program. Robert S. Willard, Manager of Government Markets at Mead Data Central, Inc., has stated, "It is a matter of public record that the Information Industry Association has generally been pleased with the OMB A-130 Circular."

These policies of the 1980 s continue into the 1990 s, with proposed revisions to both A-130 and the Paperwork Reduction Act having the power to effect substantial changes in the Depository Library Program. The public's free and equitable access to information produced by its government is, presumably, currently guaranteed by Title 44, United States Code, 1901 et. seq. Title 44 defines a "Government publication" as "informational matter which is published as an individual document at Government expense, or as required by law." The Code states that these publications "shall be made available to depository libraries through the facilities of the Superintendent of Documents for public information" and that "Depository Libraries shall make Government publications available for the free use of the general public."

The advent of new technology, including CDROMs and online access to information, has prompted OMB and others to look anew at these definitions and to reassess which information products should be included in the depository program. On January 4, 1989, OMB issued proposed revisions to A-130. ${ }^{8}$ Under these revisions, A-130 would also apply to information in electronic formats. OMB would tell agencies how to decide whether to disseminate information in electronic format and establish guidelines for agencies on ways to avoid "unfair competition" with the private sector. After receiving more than two hundred negative responses from concerned librarians and others, OMB withdrew these proposals in June 1989.

The principles embodied in the January 1989 A-130 criteria, however, have now resurfaced in statutory language in the 1989 proposed amendments to the Paperwork Reduction Act (PRA) and in the Government Printing Office Improvement Act of 1990, two measures on the agenda of the 101st Congress, 2nd Session. The Paperwork Reduction And Federal Resources Management Act of 1989 (H.R. 3965) and its companion bill, The Federal Information Resources Management
Act of 1989 (S. 1742), do recognize the role of depository libraries in the dissemination of government information. Both bills require agencies to provide government publications in electronic format to the Superintendent of Documents for distribution to libraries. Other sections of the proposed legislation, however, substantially increase OMB's power to regulate agencies' information dissemination activities and enhance OMB's budgetary control over the agencies producing the information. Many librarians fear that this legislation establishes OMB as an "information czar" whose ties to the private sector will result in the privatization and selling of even more government information which used to be distributed through the depository library system for the free and equitable use by all. Both critics and proponents of this legislation agree that the bill is a compromise by the information industry, public interest groups, and OMB officials and represents a considerable revision of the philosophy behind Title 44 and its predecessors in 1812 and 1869.

\section{In assessing the role of Congress and $\mathrm{OMB}$, libraries and librarians need to assess their roles in the formation of government information policy and the effect library policies have on the Depository Library Program.}

Adding to depository librarians' apprehensions about language in H.R. 3965 and S. 1742 is language in the Government Printing Office Improvement Act (H.R. 3849). This act amends Title 44, United States Code, "to reform the public information functions of the Public Printer and the Superintendent of Documents" by adding the following to section 1902 :

\footnotetext{
Access to information services may be made available to depository libraries by the Superintendent of Documents subject to agreement between the Superintendent and the component of the Government issuing the service. Such an agreement must describe the terms and conditions of access, including arrangements for cost sharing, such as contributions from service users, depository libraries, the issuing component of Government, and appropriations for the depositiory library program. ${ }^{\theta}$
}

As the Government Documents Round Table (GODORT) of the American Library Association wrote in a letter to the bill's proponent, Congressman Jim Bates of California, this is "a change in 
Congress's policy of providing access to government information in depository libraries without direct cost to the users. The implication that these services might not be available unless 'contributions' are made by depositories and users is of serious concern to us. ${ }^{10}$

The Association for Research Libraries and the American Library Association have responded to Congress that both public and private institutions with depository library collections are already cost-sharing partners in the delivery of government information to the public by providing building space, staff, and intermediary services between the government and the information users. A survey of sixty-five regional and selective depositories revealed a collective annual budget of some $\$ 20$ million allocated to the depository collections in their libraries. Compare this to the total of $\$ 25$ million that it cost the federal government in 1989/90 to distribute millions of publications to the 1400 depository libraries. ${ }^{11}$

\section{Information gaps are wider and more frequent.}

In assessing the role of Congress and OMB, libraries and librarians need to assess their roles in the formation of government information policy and the effect library policies have on the Depository Library Program. Title 44, Section 1911, states, "Depository libraries shall make Government publications available for the free use of the general public." Most libraries have interpreted this to mean "house" or "store" depository collections, usually uncataloged and little publicized. Is it true, as Bruce Morton, Assistant Dean of Public Services at Montana State Libraries, asserts, "that libraries use depository status to build their collections for their most immediate clientele and not for the people of any Congressional district"? ${ }^{12}$ Most documents librarians have experienced the difficulties of arguing a case for the actual and potential user of government publications to library administrators, urging that documents be represented in the public catalogs of their libraries. But most libraries have had their own version of OMB's Circular A-130: the cost of providing access to government publications received in the depository program must not exceed the expected public benefits and use of them. There are too many stories, over the years, about the "weird materials" that showed up in daily boxes from Washington which were relegated to the basement, to closets, to the trash. If the question, "Have we really delivered documents to the people?" is answered "no" by depository libraries and librarians, then it is surprising that federal information policy has not previously encompassed the privatization of government information and the elimination of the Depository Library Program. Yes, libraries do share significant costs in the program, as has already been noted, but the collection of that cost data, or even the idea of collecting that data, is a relatively recent phenomenon which has emerged only in the face of the potential loss of the materials received through the Depository Library Program. A case of too little, too late? The situation is as Pogo described it when he emerged from the swamp and said, "We has met the enemy, and he is us."

What do the thirty-four federal depository libraries of North Carolina, or any depository library, have to lose by the changes in federal information policy? Many government publications have been simply eliminated, including the 1800 titles that then Presidential Counselor Edwin Meese III and Joseph Wright, Deputy Director of the Office of Management and Budget, were photographed stuffing into a trash bag at a 1984 White House "media event" extolling the virtues of government economy. Depository libraries increasingly must pay for titles which have been eliminated from the depository program, privatized, and offered for sale by commercial vendors. Top (Trade Opportunities Program) Bulletin was available to the depository libraries free of charge until October 1987. The database was then turned over to a commercial publication, Journal of Commerce, which sells for $\$ 175.00$ a year. The U.S. Census Bureau computer tape of zip code information, compiled from the 1980 decennial census, was turned over to CACI Source Products, a commercial publisher who "enhanced" the database, produced it in book form as Sourcebook of Demographics and Buying Power for Every Zip Code in the U.S.A. and sold it to, among others, depository libraries which should have received the information free along with other 1980 census materials. Price for the one volume is $\$ 675.00$. Shock and Vibration Digest, a U.S. Naval Research

\section{When private vendors elect to sell only that public infor- mation that is profitable to them, the result is a form of censorship.}

Laboratory publication formerly distributed through the depository system, now costs over 
$\$ 200$ a year from a commercial vendor. Information gaps are wider and more frequent. Administrative Notes, the newsletter of the Federal Depository Library Program, lists increasing numbers of publications that agencies either are no longer publishing due to budget restraints or because they have insufficient copies to supply to the Government Printing Office for distribution. Among these publications are Outlook 89: the 65th Annual Agricultural Outlook Conference, Annual Energy Outlook 1988, and many monthly issues of serials publications, such as the April 1988 issue of Arms Control Update and the March 1989 list of GAO reports. As more information is produced in electronic format, depository libraries are faced with peculiar situations. Some Census Bureau CD-ROMs are supplied in the depository shipments, but the software necessary to access them must be purchased from a private vendor. While the role of the private sector in providing online ] access to the numerous federal databases is being debated by Congress, the depository libraries have no access to this information unless they pay access fees and telecommunications costs. It is as if the outcome is already decided before the debate is finished.

Obviously, libraries, if they wish to continue to receive government-produced information, will need to allocate more of their collections budgets for these materials. But user fees, either implemented by libraries or mandated by statute, create "information haves" and "information have-nots." They do not perpetuate a society "characterized by formal equality of rights and privileges." When private vendors elect to sell only that public information that is profitable to them, the result is a form of censorship. These are but a few of the more immediate effects. Future, and as yet unknown, consequences will undoubtedly follow. Certainly documents librarians, and others, know that we have less and less access to less and less information by and about our government. The

\section{...we have less and less access to less and less infor- mation by and about our government.}

words of James Madison are as relevant now, to all parties involved in the process, as they were in 1822. The Play is beginning!

\section{References}

1. Webster's Third New International Dictionary (Springfield, MA: Merriam-Webster, 1981), 600.

2. James Madison in a letter to W. T. Barry, August 4, 1822.

3. U.S. Congress. Joint Committee on Printing, Government Depository Libraries: The Present Law Governing Designated Depository Libraries (Washington: Government Printing Office, 1983), 4.

4. 15 Stat. 292.

5. 94 Stat. 2812

6. 50 FR 52736 .

7. "Whose Information Is It Anyway? The Privatization of Government-Produced Information," Government Publications Review 13 (May-June 1986):325.

8. 54 FR 214-220.

9. HR 3849 Sec. 5(b).

10. Susan Tulis, GODORT Chair, in a letter to Congressman Bates, January 10, 1990.

11. Eileen Cooke, Director, ALA Washington Office, in a letter to Congressman Bates, January 20, 1990.

12. Bruce Morton, "Perceptions of Power, the People, and Future Access to U.S. Government Information," DTTP (Documents to the People) 17 (March 1989):9.

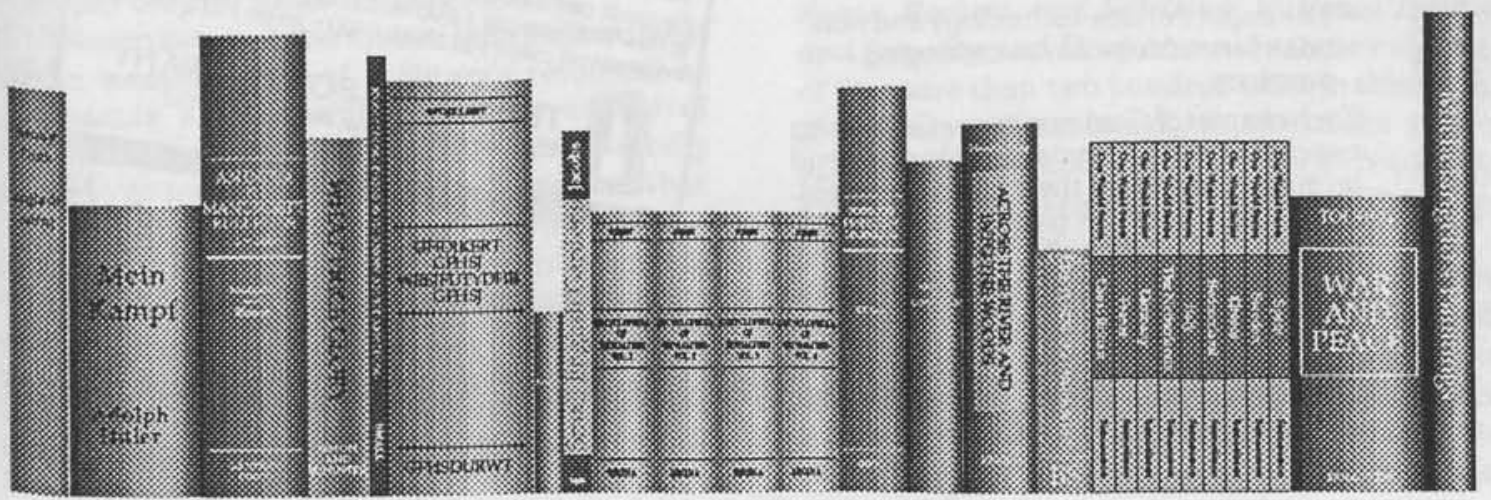




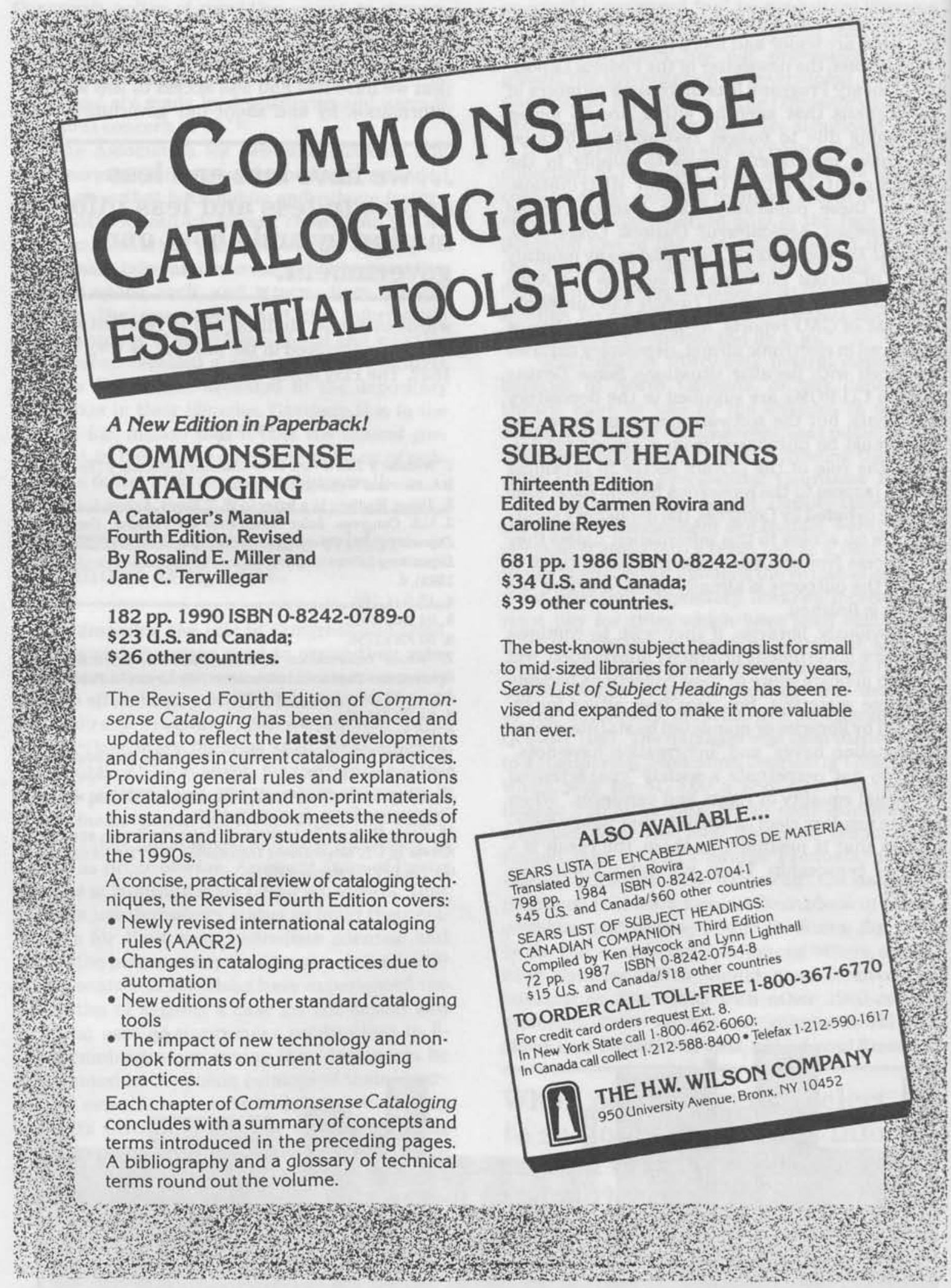

